\title{
The Formulation Model of Rural and Urban Land and Building Tax (PBB-P2) For Increasing the Local Original Revenue in Ngawi District
}

\author{
Changgih Swantaka Yoganendi ${ }^{1}$ \\ Agus Riewanto ${ }^{2}$ \\ Sunny UmmulFirdaus, ${ }^{3}$ \\ 1 Student of Postgradyate Study of UNS Surakara \\ 2,3 Lecturer of Postgraduate Study of UNS Surakarta
}

\begin{abstract}
Every State which declares itself to be an independent State must have a goal to be achieved. As one of the independent countries, Indonesia has the objectives listed in the fourth paragraph of the opening of the basic constitution namely the 1945 Constitution of the Republic of Indonesia (hereinafter abbreviated to the 1945 Constitution), among others, to protect all the people of Indonesia and all of Indonesia's blood and to promote public welfare, educating the life of the nation, and participating in carrying out world order based on freedom, eternal peace and social justice.
\end{abstract}

\section{INTRODUCTION}

One of the sector that is also undergoing renewal is the area of regional government with the idea commonly known today as regional autonomy - based on the principle of decentralization -. If there is a historical flashback, state policy reconstructs the paradigm as well as the government system through the decentralization model which is actually a means of structuring relations between the Central and Regional Governments towards a more democratic direction by increasing the portion of decentralization through granting authority to the regions - to administer the government. With the change in the government system, automatically various supporting institutions for the system that have been centralized are also experiencing changes. ${ }^{1}$

The change and transition of the paradigm was then adjusted to the socio-political constellation that was developing at that time in which the characteristics of the central government regime also influenced the center's view of the region. These various perspectives are then put together in a forum for regulation in the regional sector, starting with the publication - counting since the reform era - Law Number 22 Year 1999 - which subsequently underwent several changes and amendments - until Law Number 9 Year 2015 which was in force when this.

The burden resting on local governments can have logical implications, given the condition of the cultural, social, and economic structure of the community which rarely experiences sectoral deterioration but rather leads to

1 See Ari Dwipayana dan Sutoro Eko, Building Good Governance in the Rural Area, IRE Press, Yogyakarta, 2003, page. 1-3. the escalation of various sectors. For this reason, local governments take a principal role in this regard. The availability of detailed social services and arrangements for many community activities in the economic field have raised macro and micro expectations from all lines. On the basis of this, the regional government is expected to be better able to explore financial resources, especially to meet the needs of government financing and development in the region through Regional Original Revenue (PAD). ${ }^{2}$

In line with the above expectations, the sources of regional income actually become a fundamental instrument for upholding development in regions that basically require an insufficient amount of funding sources to ensure the continuity of the development of the regions concerned. To carry out real, extensive and responsible regional autonomy while increasing the ability to carry out planning, organizing and mobilizing development, each region needs the authority and ability to explore existing resources in their respective regions. The logical consequence is the granting of power to the regions in collecting funding in the implementation of regional autonomy, as a manifestation of the principle of decentralization in order to increase local revenue which is expected to be sublimated from year to year. For this reason, it is necessary to extract sufficient regional funds to support the successful implementation of development and autonomy. ${ }^{3}$

One of the aspects which becomes the source of local revenue is the tax sector. As it is known that tax is one of the sources of financing for national development in the context of improving people's welfare. Taxes are used to finance public expenditures related to the duty of the state to administer government. ${ }^{4}$ Furthermore, with regard to the area of taxation and regional government, a new momentum is present for the Regional Government when Law Number 28 of 2009 concerning Regional Taxes and

\footnotetext{
${ }^{2}$ Lies Ariany, "Local Revenue from the Tax Sector in the Context of the Implementation of Regional Autonomy ", Legal Issues, Vol. 39, No. 3, Faculty of Law, Diponegoro University, Semarang, 2010, page. 231.

3 Lihat Pheni Chalid, Regional Autonomy Issues, Empowerment, and Conflict, Partnerships, Jakarta, 2005, page. 5 .

${ }^{4}$ Santoso Brotodiharjo, Introduction to Tax Law, Eresco Bandung, Bandung, 1987, page. 2.
} 
Regional Retribution is legally put in place. Specifically for Regency/ City Regional Governments, through this Law Regency/ City Regional Governments have been delegated authority by the Central Government in terms of managing the Rural and Urban Land and Building Tax (PBB-P2). ${ }^{5}$

This delegation of authority was intended with the intention to: (1) the increase of accountability in the implementation of regional autonomy; (2) the expansion of the regional tax base; (3) the granting of authority in determining tax rates; (4) an increase in regional ownsource revenue (PAD) as an instrument for budgeting to carry out regional policies. ${ }^{6}$ With this delegation, all process activities from data collection, assessment, determination, administration, collection/ billing to PBB-P2 services are carried out by the Regency/ City Regional Government. (Author's thick line) ${ }^{7}$

Based on the explanation above specifically regarding the management of the Rural and Urban Land and Building Tax (PBB-P2) which is tolerated by the area of land owned by each region, the PBB-P2 has great potential as a contributor to PAD in a certain region. For this reason, through the authority held by the regions, the optimization of increasing PAD through PBB-P2 becomes a logical option that should be developed through various policies, one of which is through reformulation of the PBB-P2 based on a progressive model. On the basis of this also, the authors then took the location of the study in Ngawi Regency considering the geographical structure with an area of Ngawi Regency is $1,298.58 \mathrm{~km} 2$, where about 40 percent or around $506.6 \mathrm{~km} 2$ are paddy fields. ${ }^{8}$

Juridical perspective, regulation regarding land and building tax in rural and urban areas in Ngawi Regency is based on the provisions contained in Ngawi Regency Regulation No. 1 of 2012. The emergence of these Regional Regulations is based on the provisions contained in Article 2 paragraph (2) letter $\mathrm{j}$ of the Law Law No. 28/2009 concerning Regional Taxes and Regional Retributions which states that the Land and Building Tax which was previously a central tax has fully become the authority of the Regional Government. ${ }^{9}$

On the other hand, the potential of PAD through PBBP2 Ngawi Regency is actually quite large. The authors based this on the available data where the potential of PAD

${ }^{5}$ See Article 2 paragraph (2) letter J of Law Number 28 Year 2009 concerning Regional Taxes and Regional Levies.

${ }^{6}$ See Explanation of Law Number 28 Year 2009 concerning Regional Taxes and Regional Retribution.

7 Seehttp://www.pajak.go.id/content/pengalihan-pbbperdesaan-dan-perkotaan accessed on May 28, 2018 at 02.08 PM.

${ }^{8}$ Seehttps://ngawikab.go.id/ accessed on May 28, 2018 at 11.32 PM.

${ }^{9}$ Consideration of Ngawi Regency Regulation Number 1 of 2012 concerning Rural and Urban Land and Building Taxes.
Ngawi Regency through the PBB-P2 sector only contributed $11 \%$ of PAD in the 2014 fiscal year, $10.67 \%$ in the 2015 fiscal year, $9.6 \%$ in the 2016 fiscal year and $9.6 \%$ in fiscal year 2017.

\section{PROBLEM STATEMENTS}

How is the Formulation of Provisions in the Ngawi Regency Regulation Number 1 of 2012 concerning the Land and Building Tax on Rural and Urban Areas (PBB$\mathrm{P} 2$ ) in order to increase the local revenue (PAD) in Ngawi Regency?

\section{LITERATURE REVIEW}

\section{A. Regional autonomy}

The term autonomy comes from the Greek word autos which means itself and namos which means Law or rules. Thus autonomy can be interpreted as the authority to regulate and manage their own households (Bayu Suryaninrat; 1985). Moving on from the above formula, it can be concluded that regional autonomy in principle has three aspects, such as:

$>$ Aspects of Rights and Authority to manage and manage their own households.

$>$ Aspects of the obligation to continue to follow the rules and regulations of the government above, and remain within one national government framework.

$>$ Aspects of independence in financial management both from the cost as the delegation of authority and the implementation of obligations, also especially the ability to explore sources of self-financing.

The positive impact of regional autonomy is that with regional autonomy then the regional government will have the opportunity to display the local identity that is in the community. The reduced authority and control of the central government has received a high response from regional governments in dealing with problems that are in their own regions. The negative impact of regional autonomy is the opportunity for persons in the local government to take actions that can harm the state and people such as corruption, collusion and nepotism. In addition, sometimes there are regional policies that are not in accordance with the State constitution that can lead to conflict between one region and its neighbors, or even areas with the State.

\section{B. Theory of State Finance}

In general, state finance is defined as all matters related to the issue of state revenue and expenditure. Suparmoko stated that the State finance is a study of the effects of the State Budget (APBN) on the economy, especially the effect on the achievement of the objectives of economic activity, price stability, equitable income distribution and increased efficiency and the creation of employment opportunities. ${ }^{10}$

\footnotetext{
10 Supramoko, Economic Development, BPFE UGM, Yogyakarta, 1992.
} 
According to M. Ichwan, as cited in W. Riawan Tjandra, state finance is a quantitative activity plan (with figures of which are realized in the amount of currency), which will be carried out for the future, usually one year later. ${ }^{11}$ According to Geodhart as quoted by Alfin Sulaima, state finance is a total periodic stipulated law that gives government power to carry out expenditures for a certain period and shows the financing tools needed to cover these expenses. $^{12}$

Furthermore, according to the opinion of Arifin P. Soeria Atmadja, state finance in terms of accountability by the government, that state finance that must be accounted for by the government is state finance that only comes from the state budget. So that what is meant by state finance is finance that comes from the state budget. Arifin P. Soeria Atmadja describes the dualism of the definition of state finance, namely the understanding of state finance in a broad sense and the understanding of state finance in a narrow sense. The definition of state finance in the broad sense referred to is finance originating from the State Budget, Regional Budget, Finance of State Business Units or state-owned companies and in essence all state assets. While the definition of state finance in the narrow sense is finance that comes from the state budget only. ${ }^{13}$

State finance actually has a broad meaning, which is in addition to covering state property or state wealth which does not solely consist of all rights, also includes all obligations. These rights and obligations can only be assessed in cash if implemented. ${ }^{14}$ As explained by $\mathrm{M}$. Subagio that state finance is the rights and obligations of the state that can be valued in money, so also everything either in the form of goods or goods that are owned by the state in connection with the implementation of those rights and obligations. ${ }^{15}$

Based on the opinion of M. Subagio, it appears that the elements of state finance, namely money and goods that are owned by the state, state assets, rights and obligations that can be valued in money. Countries have rights that according to their needs can be assessed by using money, for example: ${ }^{16}$ :

The right to tax citizens, whose levies are only necessary or based on enforceable laws, without giving direct compensation to the taxable person.

11 W. Riawan Tjandra, State Financial Law, Grasindo, Jakarta, 2006, page. 1-2.

${ }^{12}$ Alfin Sulaiman, State Finance in SOEs in the Perspective of Legal Studies, Alumni, Bandung, 2011, page. 20.

${ }^{13}$ Arifin P. Soeria Atmadja, State Financial Accountability Mechanism, Gramedia, Jakarta, 1986, page. 49.

${ }^{14}$ Lihat Yuswar Zainul Basri and Mulyadi Subri, State Finance and Foreign Debt Policy Analysis, PT. Raja Grafindo Persada, Jakarta, 2003, page.1-2.

${ }^{15}$ M. Subagio, RI State Financial Law, Rajawali Press, Jakarta, 1991, page. 11.

${ }^{16}$ Yuswar Zainul Basri and Mulyadi Subri, loc.cit
Countries can print banknotes or coins. Procurement of legal payment instruments is the duty of the government.

$>$ Obligations to carry out state duties in the interest of the community, such as maintaining security and order, building and repairing highways, ports and air bases, building school buildings, hospitals, reservoirs, making and maintaining irrigation, and building and maintaining transportation equipment.

$>$ Obligation to pay for invoicing rights from parties who carry out something or an agreement with the government, for example the purchase of goods for government needs (state or people), construction of government buildings and so on.

Normative juridical perspective, Article 23 of the 1945 Constitution of the Republic of Indonesia states that:

$>$ The State Budget (APBN) is determined annually by law. If the House of Representatives (DPR) does not approve the budget proposed by the government, the government carried out the budget last year.

$>$ All taxes for state purposes are based on the law.

$>$ Types and prices of currencies are determined by law.

$>$ State finance matters are further regulated by law.

$>$ To examine the responsibility regarding state finances, a Supreme Audit Agency (BPK) is established, the regulation of which is determined by law.

Furthermore, Article 1 number 1 of Law Number 17 of 2003 concerning State Finance provides a definition of state finance, namely: "State finance is all rights and obligations of the state that can be valued in money, as well as everything in the form of money or in the form of goods that can be become state property in connection with the implementation of these rights and obligations. "Furthermore, in Article 2 of Law Number 17 of 2003 concerning State Finances states that: State Finance as referred to in article 1 number 1 , includes:

- The state's right to collect taxes, issue and circulate money, and make loans;

- The state's obligation to carry out general government service duties and pay third party bills;

- State Revenue;

- State Expenditures;

- Regional Revenue;

- Regional Expenditures;

- State assets/ regional assets that are managed alone or by other parties in the form of money, securities, receivables, goods, and other rights that can be valued with money, including assets that are separated in state/ regional companies;

- The assets of other parties controlled by the government in the implementation of governmental tasks and/ or public interest;

- Other parties' assets are obtained by using facilities provided by the government.

Then, the state finances as referred to in the elucidation of Article 2 and Article 3 of Law Number 31 of 1999 concerning Eradication of Corruption Crime Act 
amended by Law Number 20 of 2001 concerning Eradication of Corruption Crime are all state assets in whatever form are separated or separated not separated including all parts of state assets and all rights and obligations arising from: Being in the possession, management and accountability of state agency officials, both at the central and regional levels; Being in control, management and responsibility of State-Owned Enterprises/ Regional-Owned Enterprises, foundations, legal entities and companies that include state capital, or companies that include third party capital based on agreements with the state.

\section{Legal System Theory}

Before coming to a more discussion on the legal system theory according to Lawrence M. Friedman, it is better to know the opinion of Hans Kelsen about the legal system. Kelsen said that the legal system is a norm system. Then Kelsen emphasized that a norm system is said to be valid if it is obtained from a higher norm above it, which subsequently reaches the level where the norm cannot be obtained from another higher norm, this is called the basic norm. ${ }^{17}$

Based on the nature of these basic norms Hans Kelsen divides the system of norms into two types namely static norm systems and dynamic norm systems. Static norm systems can only be found through an intellectual work order, that is, through inference from general to specific. While the dynamic norm system is a norm beyond which we can no longer find norms higher than it, and cannot be obtained through an intellectual work order. ${ }^{18}$ From Kelsen's view it can be simplified that the norm system called the legal order is a system of dynamic type because in a dynamic norm system, the validity of the norm is obtained from the delegation of authority based on the country's legal system either the formation of norms by parliament, or born out of habit or established by the court. ${ }^{19}$

Hans Kelsen's view of the legal system mentioned above in our opinion is true, but it certainly does not cover the whole of what is meant in the legal system itself. Is the law only limited to products made or formed either by Parliament, customs or court decisions? then what about prosecutors, police and lawyers aren't they also part of law enforcement? Then, where is the position of the community as implementing norms with values and expectations of personal or group conditions in their social life?

Of course all of these are components that cannot stand alone, when the parts do not run optimally, we are talking about effectiveness. However, in the context of writing this paper, we limit it to issues concerning the application of legal norms in the legal system based on Lawrence Friedman's view, so that the issue of legal effectiveness that also has a connection will not be reviewed because it is feared to be too wide and too broad.

\footnotetext{
${ }^{17}$ Ibid, hlm. 161.

${ }^{18}$ Ibid, page. 163 .

${ }^{19}$ Ibid, page. 163 .
}

Therefore, to answer the question above, we will explain the legal system according to Lawrence Friedman. Friedman divides the legal system into three (3) components such as: $:^{20}$

$>$ The substance of the law (substance rule of the law), which covers all written and unwritten rules, both material and formal law.

$>$ Legal structure (structure of the law), covering legal institutions, legal apparatus and law enforcement systems. The legal structure is closely related to the justice system implemented by law enforcement officers, in the criminal justice system, the application of law enforcement is carried out by investigators, prosecutors, judges and advocates.

$>$ Legal culture (legal culture), is an emphasis on the culture in general, habits, opinions, ways of acting and thinking, which direct the social forces in society.

The three components of the legal system according to Lawrence Friedman mentioned above are the soul or spirit that moves the law as a social system that has a special character and technique in its study. Friedman dissects the legal system as a process that begins with an input in the form of raw materials in the form of sheets of paper in a draft lawsuit filed in a court, then the judge manages the raw materials to produce output in the form of a decision. ${ }^{21}$

Input in the form of a lawsuit or indictment concept in a system is an element of social attitudes and values for the demands of the community that drives the legal system. If people do not make demands on values and attitudes that they think are contrary to their expectations either individually or in groups, then there will be no concept of lawsuit or indictment that will go to court. If there is no claim or indictment as input in the system, the court will not work and will never exist. ${ }^{22}$ Therefore, each component in the legal system is an inseparable part if one component does not move there will be no feedback that moves the system.

But surely a legal system is not a machine that works with definite mechanisms and processes. Lawyers with ideal ideas want law to be definite, predictable, and free from subjective things in other words the law must be highly programmed, so that every input that is entered and processed will produce definite and predictable outputs. Therefore, anything that has an output other than that will be considered unfair. ${ }^{23}$

The ideal ideasmentioned above are ideas that are impossible to realize in the common law system or the civil law system. It is inseparable from the unique and special character of the legal system as a specific social science. As expressed by Friedman that those who play an important

\footnotetext{
${ }^{20}$ See in Lawrence M. Friedman, The Legal System; A Social Science Perspective, Russell Sage Foundation, New York, 1975, page. 12-16.

${ }^{21}$ Ibid, page. 13 .

${ }^{22}$ Ibid, page. 13.

${ }^{23}$ Ibid, page. 14 .
} 
role in a court process are judges and lawyers. The judges in deciding the case they hear are inseparable from various factors, both background, attitude, values and intuition. One study showed that Democrats at the Michigan Supreme Court were more sensitive than Republicans to unemployment demands. ${ }^{24}$ Stuart Negel measures the role of lawyers in each judicial process based on the background, expertise, and experience of lawyers in decisions. As a result he found that older and richer lawyers tended to win cases. ${ }^{25}$

From the above description, it can be seen that the legal system that starts from the input and then is processed and produces output in the form of a decision is a mechanism that cannot be ascertained and predicted. The complexity affecting the system makes the application of law in the context of justice very subjective and highly dependent on the perspective of the judge and is inseparable from the influence of the lawyers who make legal arguments in order to convince the judge in deciding.

\section{RESEARCH METHOD}

The type of research used in this thesis is empirical legal research. This research is analytical descriptive, which describes the data obtained from observations, interviews, documents and field notes, then analyzed as outlined in the form of a thesis to describe the problem with the chosen title, and seen from the approach this research uses normative juridical.

\section{DISCUSSION}

The PAD revenue posture of Ngawi Regency from the PBB-P2 sector did not experience a significant change, compared to previous years, the findings in the field showed that the Tax Sector Revenue only contributed an average of $10 \%$ to the PAD. Seeing so minimal acceptance of the Ngawi Regency PBB-P2 sector from the 2014 fiscal year to the 2017 fiscal year to the PAD each year, it actually requires innovation through a set of policies. As mandated in Law No. 28/2009 concerning Regional Taxes and Regional Restrictions, the Regional Government is given the freedom in the form of a description in determining the amount of local tax rates that are adjusted to the conditions and characteristics of each region with the condition that they do not exceed the highest tariff rates of $0.3 \%$ listed in Law Number 28 of 2009 concerning Regional Taxes and Regional Levies. Article 7 of the Ngawi Regency Regulation No. 1 of 2012 concerning Rural and Urban Land and Building Taxes states that the Land and Building Tax Rates are determined as follows:

$>0,2 \%$ (zero point two percent) for NJOP Rp1.000.000.000,00 (one billion rupiah) or more; and

$>0,1 \%$ (zero point two percent) for NJOP less thanRp1.000.000.000,00 (one billion rupiah).
Considering the comparatively low tariffs of PBB (Land and Building Tax) and the gap to increase PBB-P2 tariffs, thus, the increase in PBB tariffs P2 in Ngawi Regency must be updated by updating the Regional Regulation so that it is expected to stimulate PAD in Ngawi Regency to obtain higher potential.

The innovation that is deemed appropriate is by applying Progressive-based Rural and Urban Land and Building Taxes. In a developing country, development is being actively carried out and this situation is driving the creation of changes that occur in the community. In such circumstances clearly the law will not be able to only play a role as a means of social control; the law will be left behind by the developments that occur. In order to anticipate the situation that occurs in the community, the law needs to play another role in accordance with its function as a means to make changes in society. The law must be able to be used as a means to open new roads and channels in people's lives, so that development can be carried out smoothly and regularly.

Regions that have successfully implemented the P2 Progressive PBB are DKI Jakarta. Article 6 Regional Regulation of the Province of DKI Jakarta Number 16 Year 2011 concerning Land and Building Tax, there are four classifications of determining PBB-P2 tariffs in Jakarta, as follow $^{26}$ :

$>$ Tariffs $0.01 \%$ for NJOP less than Rp. 200 Million

$>$ Tariffs $0.1 \%$ for NJOP Rp.200 Million s/d Rp. 2 Billion

$>$ Tariffs $0.2 \%$ for NJOP Rp.2 Billion s/d 10 Billion

$>$ Tariffs $0.3 \%$ for NJOP Rp. 10 Billion or more

As seen from the type of progressiveness DKI implements a Progressive PBB based on an idle land tax carried out with a progressive scheme based on land ownership. That is, the more extensive or more expensive land ownership by a body or private, the tax that will be imposed on him will be higher. Related to efforts to boost PAD, DKI Jakarta Provincial Government implements a number of political and administrative processes as part of policy implementation activities. Specifically the implementation of progressive PBBP2 tariffs in 2014 became the most crucial thing considering the DKI Jakarta Provincial Government is trying to significantly increase its PAD. PAD in 2014 to IDR39.55 trillion increased 50.6\% from the previous IDR26.26 trillion in the 2013 APBDAmendment of DKI.

Progressive Tariff Adjustments can be adopted as an effort to increase PAD in Ngawi. The NJOP adjustment will certainly have an impact on the increase in PBB-P2 that must be paid by taxpayers, in addition to being affected by the vastness of the earth, the area of the building plus the value of the building and the tax rate, of course with modifications according to the conditions and conditions in Ngawi. For example, by changing the tax rate using 3 different rates.

${ }^{24}$ Ibid, page. 228 .
${ }^{25}$ Ibid, page. 228 .

${ }^{26}$ See DKI Jakarta Provincial Regulation Number 16 years 2011 
Article 7 of the Ngawi Regency Regulation No. 1 of 2012 concerning Rural and Urban Land and Building Taxes states that the Land and Building Tax Rates are set as follows:

$>0,2 \%$ (zero point two percent) for NJOP Rp1.000.000.000,00 (one billion rupiah) or more; and

$>0,1 \%$ (zero point one percent) for NJOP less thanRp1.000.000.000,00 (one billion rupiah).

Changed into:

$>$ Tariffs $0.05 \%$ for NJOP less than Rp 500 Million

$>$ Tariffs $0.15 \%$ for NJOP more than Rp 500 Million to Rp 5 Billion

$>$ Tariffs $0.2 \%$ for NJOP more than Rp 5 Billion

Thus, it is combined with several progressive models. There are several Progressive UN models that can be adopted for PBB-P2 in Ngawi, First is the capital gain tax, in which the land transaction tax will be replaced by the scheme. Later, a tax will be imposed on the added value of the price of land. Looking at the case examples, for example there is a piece of land with an acquisition price of Rp. 100 million. Within a certain period of time this land was then sold at Rp. 500 million. This means that there is a difference of Rp. 400 million. This figure will be taxed, for example 5 percent. Means the tax is 5 percent $x$ Rp 400 million in the amount of Rp 20 million. The second is the unutilized asset tax. This scheme makes companies or individuals who own vast land without having a clear plan to pay taxes. In other words, a "landbank" tax will apply. In principle, unproductive land will be taxed.

Procedure for applying criminal sanctions must go through a judicial process. The internal cumulation is the application of two or more administrative sanctions together, for example the termination of administrative services and / or revocation of permits and/ or the imposition of fines. The application of sanctions jointly between Administrative Law and other laws can occur, namely internal cumulation and external cumulation. External cumulation is the application of administrative sanctions together with other sanctions, such as criminal sanctions or civil sanctions. According to Hans John, there are two types of tax sanctions, as follow:

$>$ Criminal Sanction is a sanction imposed by a criminal judge in a decision (vonnis) in his/her trial to someone, whether he/she is a taxpayer, a person who has not been a taxpayer or a tax official, who has committed acts in the field of taxation that meet the formulation of the Act by the Act - Being threatened with criminal sanctions.

$>$ Administrative sanctions, their nature and implementation are different from criminal sanctions. Administrative Sanctions are penalties imposed by Administrative officials against taxpayers who violate the provisions of the Qualified Law which are lighter than criminal acts, which are always in the form of money, either a fixed amount or a multiplication or percentage of the amount of tax owed. Administrative sanctions for the UN obligation have been regulated in the UUPBB, namely Article 9 Paragraph (2), Article 10
Paragraph (2), (3) and Paragraph (4) and in Article 11 Paragraph (3) of the UUPBB are as follows:

- An administrative fine of $25 \%$ is calculated from the tax base for taxpayers who do not submit Tax Object Notification Letter (SPOP) even though it has been rebuked in writing as formulated in Article 9 Paragraph (2) and Article 10 Paragraph (2) letter a and Paragraph (3) UUPBB.

- An administrative fine of $25 \%$ of the tax difference owed to taxpayers reporting incorrect tax object data (smaller than the result of the Inspectorate of Tax Generals). This matter has been formulated in Article 10 Paragraph (2) letter $b$ and Paragraph (4) of the UUPBB.

- An administrative fine of $2 \%$ is charged a month, which is calculated from the due date until the day of payment. For a maximum period of 24 months for the tax due when the payment is due is not paid or the payment is underpaid, as formulated in Article 11 Paragraph (3) of the United Nations Law.

In imposing administrative sanctions carried out by the state apparatus consisting of functionaries/ officials or state institutions that are given the authority and obligations based on statutory regulations, to carry out all the provisions specified in tax laws.

Based on experience even though many legal regulations contain weaknesses or deficiencies, but in reality these legal regulations can successfully approach a sense of justice. The level of community legal awareness is influenced by public knowledge of various aspects of the existing law, in this case the image and awareness of the community can be fostered and enhanced through efforts such as counseling, guidance, example, and community involvement in overcoming problems or obstacles faced, Therefore, the increase in educative-persuasive and preventive dimension of law enforcement activities needs to be increased and promoted.

\section{REFERENCES}

\section{Books}

[1]. Abdul Gafar Karim. 2003. The Complexity of Regional Autonomy Issues in Indonesia. Yogyakarta: Pustaka Pelajar.

[2]. Abdurrahman (Ed). 1987. Several Thoughts on Regional Autonomy. Jakarta: Media Sarana Press.

[3]. Achmad Ali. 2009. Revealing Legal Theory and Judicial Theory, including Interpretation of the Law (Legisprudence). Jakarta: Kencana.

[4]. Afan Gaffar Syaukani dan Ryaas Rasyid. 2009. Regional Autonomy in the Unitary State. Yogyakarta: Pustaka Pelajar.

[5]. Ahmad Yani. 2002. Financial Relations Between Central and Regional GovernmentsJakarta: RajaGrafindo Persada.

[6]. Aman Khan and W. Bartley Hildreth. 2002. Budget Theory in the Public Sector. London: Quorum Books.

[7]. Alfin Sulaiman. 2011. State Finance in BUMN in the Legal Knowledge Perspective. Bandung: Alumni. 
[8]. Amiruddin. 2003. Introduction to Legal Research Methodologies. Jakarta: Raja Grafindo Persada.

[9]. Amrah Muslimin. 1986. Legal Aspects of Regional Autonomy. Bandung: Alumni.

[10]. Arifin P. Soeria Atmadja. 1986. State Financial Accountability Mechanism. Jakarta: Gramedia.

[11]. Ari Dwipayana dan Sutoro Eko. 2003. Building Good Governance in the Village. Yogyakarta: IRE Press.

[12]. B.N. Marbun. 2010. Regional Autonomy 1945-2010: Process and Reality. Jakarta: Pustaka Sinar Harapan.

[13]. Bambang Sunggono. 1996. Legal Research Methodology. Jakarta: Rajawali Press.

[14]. Burhan Ashofa. 2007. Legal Research Methods. Jakarta: Rineka Cipta.

[15]. Darmawan Tri Wiowo. 2006. Dream of a Welfare State. Jakarta: LP3ES.

[16]. Dwikora Harjo. 2013. Indonesian taxation. Jakarta: Mitra Wacana Media.

[17]. Ermaya Suradinata. 2008. Building Regions Towards Rising Indonesia. Jakarta: Elex Media Komputindo.

[18]. Faisal Akbar Nasution. 2009. Regional Government and Sources of Original Regional Revenue. Jakarta: Sofmedia.

[19]. H. Bohari. 2012. Introduction to Tax Law. Jakarta: Raja Grafindo Persada.

[20]. HAW Widjaja. 2002. Regional Autonomy and Autonomy Region. Jakarta: Raja Grafindo Persada.

[21]._ 2004. The Implementation of Autonomy in Indonesia: In the Context of Socialization of Law Number 32 of 2004 Concerning Regional Government. Jakarta: RajaGrafindo Persada.

[22]. H.B Sutopo. 2006. Qualitative Research Methods. Surakarta: UNS Press.

[23]. Hans Kelsen. 2008. General Theory of Law and the State. Bandung: Nusa Media.

[24]. Harry Hartoyono dan Untung Supardi. 2010. Revealing the Management of the United Nations Administration and BPHTB, the Experience in the Central Government and the Reference for the Implementation of Local Taxes. Jakarta: Mitra Wacana Media.

[25]. Irawan Soejito. 1984. The Relationship of the Central Government and Local Government. Jakarta: Bina Aksara.

[26]. Iskandar. 2016. Intellectual Conception in Understanding Indonesian Legal Studies. Yogyakarta: AndiPublisher.

[27]. J. Kaloh. 2007. Looking for Forms of Regional Autonomy: A Solution in Answering Local Needs and Global Challenges. Jakarta: Rineka Cipta.

[28]. Juanda. 2004. Local Government Law: Tides of Authority between DPRD and Regional Heads. Bandung: Alumni.

[29]. Juniarto. 1992. The Development of Local Government. Jakarta: Bina Aksara.

[30]. Kementrian Keuangan. 2014. General Guidelines for the Management of Land and Building Taxes in Rural and Urban Areas. Jakarta: Directorate General of Fiscal Balance.
[31]. Laica M. Marzuki. 2006. Observing in the law house. Jakarta: Secretariat General of Registrar of the Indonesian Constitutional Court.

[32]. Lawrence M. Friedman. 1975. The Legal System; a Social Scince Prespective. New York: Russel Sage Foundation.

[33]. M. Subagio. 1991. RI State Financial Law. Jakarta: Rajawali Pers.

[34]. Mamesah. 1995. Regional Financial Administration System. Jakarta: Gramedia Pustaka.

[35]. Mardiasmo. 2010. Regional Autonomy and Financial Management. Yogyakarta: Publisher Andi.

[36]. Marihot. 2009. Land and Building Tax in Indonesia Theory and Practice. Yogyakarta: Graha Ilmu.

[37]. Muhammad Djafar Saidi. 2014. Tax Law Renewal. Jakarta: Raja Grafindo Persada.

[38]. Muhammad Djumhana. 2007. Introduction to Regional Financial Law. Bandung: Citra Aditya Bakti.

[39]. Mukti Fajar dan Yulianto Achmad. 2010. Dualism of Normative \& Empirical Law Research. Yogyakarta: Pustaka Pelajar.

[40]. Ni'matul Huda. 2005. Regional Autonomy "Philosophy, Development History and Problems". Yogykarta: Pustaka Pelajar.

[41]._ 2009. Local Government Law. Bandung: Penerbit Nusa Media.

[42]. Nick Devas, et al. 1989. Regional Government Finance in Indonesia. Jakarta: UI Press.

[43]. Pheni Chalid. 2005. Regional Autonomy Issues, Empowerment, and Conflict. Jakarta: Kemitraan.

[44]. Rahardjo Adisasmita. 2011. Revenue and Regional Budget Management. Yogyakarta: Graha Ilmu.

[45]. Richard Burton dan Wirawan Ilyas. 2001. Tax law. Jakarta: Salemba Empat.

[46]. Robert D. Lee, Jr, et.all. 2012. Public Budgeting Systems. Burlington: Jones and Barlett Learning.

[47]. S. Wignyosubroto (Eds). 2005. The Up and Down of Regional Autonomy: Sketches of a 100-Year Journey. Jakarta: Institute for Local Government in collaboration with the Foundation of TIFA.

[48]. Santoso Brotodiharjo. 1987. Introduction to Tax Law. Bandung: Eresco.

[49]. Soerjono Soekanto. 2006. Introduction to Legal Research. Jakarta: UI Press.

[50]. Sri Pudyatmoko. 2006. Tax law. Jakarta: Andi Offset.

[51]. Supramoko. 1992. Economic development. Yogyakarta: BPFE UGM.

[52]. Syamsuddin Haris. 2005. Decentralization and Regional Autonomy. Decentralization, Democratization and Accountability of Regional Government. Jakarta: LIPI.

[53]. W. Riawan Tjandra. 2006. State Financial Law. Jakarta: Grasindo.

[54]. Wahyudi Kumorotomo. 2008. Fiscal Decentralization: Politics and Policy Change19742004. Jakarta: Kencana.

[55]. Yuswar Zainul Basri dan Mulyadi Subri. 2003. State Finance and Foreign Debt Policy Analysis. Jakarta: Raja Grafindo Persada. 
$>$ Journal/ Articles/ Magazines/ Research/ Scientific Works

[56]. Agnes Gulo. 2013. "Regional Government Policy in Regulating Sources of Original Local Revenues (Regional Taxes and Regional Levies) in the Framework of Regional Autonomy (Study in West Nias Regency)", Thesis Masters in Law. Medan: Faculty of Law, University of North Sumatra.

[57]. Arifin Soeriaatmadja (Eds). 2010. "State Finances (Sources of State Finance) ", Final Report. Jakarta: National Legal Development Agency.

[58]. Erman Rajagukguk, delivered at the VIII National Law Development Seminar and Workshop, organized by the National Legal Development Board, Ministry of Justice and Human Rights, Denpasar 14-18 July 2003.

[59]. Jazim Hamidi. 2009. "Relationship Patterns of Central and Regional Governments", Paper at the 2009 National Seminar and End of Year Reflections, Association of Teachers of State Administration (HTN) and State Administrative Law (HAN) of East Java, Jember 27-29 December 2009Pola.

[60]. Lies Ariany. 2010. "Local Revenue from the Tax Sector in the Context of the Implementation of Regional Autonomy", Legal Issues, Vol. 39, No. 3. Semarang: Faculty of Law, University of Diponegoro.

[61]. Mudiyati Rahmatunnisa. 2015. "The Road to Decentralization Policy in Indonesia in the Reformation Era", Journal of Legal Studies, Vol. 2, No. 3, 2015. Bandung: Faculty of Law, University of Padjajaran.

[62]. Nabitatus Sa'adah. 2014. "Weaknesses in the Implementation of the Closet List System and Its Implications in Collecting Fees for Acquisition of Land and Building Rights", Legal Issues, Vol. 43, No, 1. Semarang: Faculty of Law, University of Diponegoro.

[63]. Otang Rosadi. 2015. "Constitutionality of Local Government Arrangements in Indonesia: An Experiment that is Not Finished", Journal of Legal Studies, Vol. 2, No. 3, 2015. Bandung: Faculty of Law, University of Padjajaran.

[64]. Telly Sumbu. 2010. "The Relationship between the Central Government and Local Governments in the Framework of State and Regional Financial Management, "Journal of Law Ius Quia Iustum, Vol. 17, No. 4. Yogyakarta: Faculty of Law, Indonesian Islamic University.

[65]. Tjip Ismail. 2011. "The Implementation of Regional Taxes and Regional Retribution in the era of Regional Autonomy", Legal Issues, Vol. 40, No. 2. Semarang: Faculty of Law, University of Diponegoro.

[66]. Wasisto Raharjo Jati. 2012. "Inconsistency of Regional Autonomy in Indonesia: Centralized Dilemma or Centralization", Journal of the Constitution, Vol. 9, No. 4. Jakarta: Secretariat General of the Constitutional Court.

[67]. William Sanjaya. 2015. "Constitutionality Arrangement of Deconcentration in Law Number 23 Year 2014 concerning Regional Government", Journal of Legal Studies, Vol. 2, No. 3, 2015. Bandung: Faculty of Law, University of Padjajaran.

$>$ Regulation Of The Law/ Decision Of The Judge [68]. Republic of Indonesia Constitution Amendment IV.

[69]. Law Number 9 Year 2015 concerning Second Amendment to Law Number 23 Year 2014 concerning Regional Government.

[70]. Ngawi Regency Regulation No. 1 of 2012 concerning Rural and Urban Land and Building Taxes.

[71]. Law Number 28 of 2009 concerning Regional Taxes and Regional Levies.

\section{$>$ Internet}

[72]. http://nasional.kompas.com/read/2016/09/07/2022430 1/panitera.pn.jakarta.pusat.didakwa.terima.suap.rp.2.3 .miliar.dari.lippo.groupaccessed on 7 February 2018.

[73]. https://ngawikab.go.id/accessed on 28 May 2018 at 22.32 WIB.

[74]. http://www.pajak.go.id/content/pengalihan-pbbperdesaan-dan-perkotaan diakses pada tanggal $28 \mathrm{Mei}$ 2018 Pukul 02.08 WIB. 